\title{
TEKNOLOGI BLENDED LEARNING MAHASISWA DI KOTA BATAM DENGAN METODE UNIFIED THEORY OF ACCEPTANCE AND USE OF TECHNOLOGY
}

\author{
Hendi Sama \\ Program Studi Sistem Informasi Fakultas Ilmu Komputer Universitas Internasional Batam \\ Jl. Gajah Mada, Baloi - Sei Ladi, Batam \\ hendi@uib.ac.id
}

Abstrak- Untuk meningkatkan proses pendidikan dan pengajaran oleh dosen di perguruan tinggi, pembelajaran dilakukan dengan menggunakan teknologi Blended Learning. Blended learning merupakan suatu kolaborasi dan atau kombinasi diantara pembelajaran yang mempunyai sifat tradisional (pembelajaran yang dengan melakukan tatap muka langsung) dan pembelajaran dengan memanfaatkan teknologi atau yang disebut sebagai e-learning. Penerapan teknologi Blended Learning di perguruan tinggi di provinsi Kepulauan Riau telah dilakukan di beberapa perguruan tinggi di kota Batam. Penelitian sebelumnya menyatakan bahwa terdapat permasalahan dalam penerapan teknologi Blended Learning ini. Penelitian ini meneliti bagaimana Penerimaan Teknologi Blended Learning oleh Mahasiswa di kota Batam dengan metode Unified Theory of Acceptance and use of Technology (UTAUT). Dalam pelaksanaan kegiatan penelitian ini digunakan pendekatan kuantitatif dengan desain penelitian causalistic explanatory research. Hasil penelitian ini mengungkapkan bahwa ekspektasi usaha, ekspektasi kinerja, pengaruh sosial, dan kondisi fasilitas secara bersamasama berpengaruh terhadap variabel independen Penerimaan Teknologi Blended Learning. Hal ini memperlihatkan bahwa keseluruhan Penerimaan Teknologi Blended Learning di kalangan mahasiswa sudah dapat diterima dengan baik.

Kata Kunci-Blended Learning, Unified Theory of Acceptance and Use of Technology, Pembelajaran

Abstract-In improving the education and teaching process by lecturers in tertiary institutions, learning is carried out using Blended Learning technology. Blended learning is a collaboration and / or a combination of learning that has a traditional nature (learning by doing face-to-face) and learning by utilizing technology or what is referred to as e-learning. The application of Blended Learning technology in universities in Riau Islands province has been carried out in several universities in the city of Batam. Previous research states that there are problems in the application of Blended Learning technology. This study examines how the Acceptance of Blended Learning Technology by Students in the city of Batam with the Unified Theory of Acceptance and use of Technology (UTAUT) method. In carrying out this research activity a quantitative approach is used with a causalistic explanatory research research design. The results of this study reveal that business expectations, performance expectations, social influence, and facility conditions together affect the independent variable Blended Learning Technology Acceptance. This shows that the overall acceptance of Blended Learning Technology among students has been well received.

Keywords - Blended Learning, Unified Theory of Acceptance and Use of Technology, Pembelajaran

\section{PENDAHULUAN}

Di dalam era revolusi Industri 4.0, kemajuan dan perkembangan teknologi semakin cepat dan dosen sebagai pendidik dan pengajar, tidak hanya melakukan pentransferan ilmu pengetahuan, akan tetapi juga harus mengikuti perkembangan teknologi pendidikan yang mendorong percepatan produktivitas dari aktivitas sehari-harinya. Dosen merupakan bagian integral daripada proses belajar mengajar di perguruan tinggi, yang harus terus mengembangkan kompetensinya mengikuti perkembangan zaman dan harus bisa mempunyai peran demi keberhasilan dari mahasiswa yang diasuhnya. Teknologi informasi dan komunikasi dalam pembelajaran, selain membantu mahasiswa dalam belajar, juga mempunyai peran sangat penting bagi dosen, khususnya dalam kegiatannya untuk memanfaatkan fasilitas yang ada yang digunakan untuk 
memperkaya kemampuan mendidik dan mengajar mahasiswa (Budiman, 2017).

Kegiatan dosen dalam melakukan Pendidikan dan pengajaran, sangat terhubung dalam tridharma perguruan tinggi yaitu Pendidikan dan pengajaran,

Page | 230 penelitian dan pengabdian kepada masyarakat; dimana setiap bagiannya akan menghasilkan karya ilmiah. Hasil karya dari para dosen, berada pada ranah pendidikan yang merupakan salah satu bidang yang menghasilkan inovasi yang bermanfaat bagi masyarakat.

Indonesia, sebagai salah satu negara yang mempunyai jumlah mahasiswa yang relatif banyak, yaitu 3038272 laki-laki dan 3312106 wanita (Kementerian Riset T. d., Grafik Jumlah Mahasiswa Aktif Berdasarkan Jenis Kelamin, 2019), dan jumlah dosen sebanyak 170226 laki-laki dan 133445 wanita (Kementerian Riset T. d., Grafik Jumlah Dosen Aktif Berdasarkan Jenis Kelamin, 2019); indeks inovatif Indonesia secara global masih berada pada ranking 85 (WIPO, 2019); jauh di bawah Singapore (ranking 8), Malaysia (ranking 25) dan Vietnam (ranking 42). Para dosen dan mahasiswa diharapkan dapat terus melakukan usaha untuk menghasilkan karya yang bermutu dan mendorong daya inovasi secara nasional.

Provinsi Kepulauan Riau merupakan bagian dari negara Republik Indonesia. Perkembangan teknologi Pendidikan di Kepulauan Riau sangat dibutuhkan karena akan mendukung pembangunan sektor unggulan Pariwisata (Yuwono, 2018) yang menjadi sektor penggerak utama perekonomian di provinsi Kepulauan Riau pada abad 21 (Akhirman, 2019). Faktor-faktor yang dapat mempengaruhi strategi dari pembangunan antara lain adalah kualitas sumber daya manusia terhadap penguasaan ilmu pengetahuan dan teknologi (Hendrayady, 2018).

Penguasaan ilmu pengetahuan dan teknologi juga membuat Batam, yang merupakan salah satu Kota yang berada di Provinsi Kepulauan Riau, memiliki daya saing yang tertinggi (Sinarti, Karikasari, Hendrawan, \& Wibowo, 2018), diikuti oleh Kota Tanjung Pinang, Kabupaten Bintan, Kabupaten Lingga, Kabupaten Karimun, Kabupaten Natuna, dan Kabupaten Anambas. Kriteria yang digunakan adalah Pemetaan Potensi Daerah berikut supply dan demand, penguatan seluruh infrastruktur ekonomi untuk mendorong potensi daerah, termasuk SDM nya, penguasaan rantai pasoka untuk menekan inefisiensi, peningkatan penggunaan produksi lokal dan penciptaan inovasi produk.

Inovasi yang dijalankan oleh perguruan tinggi mendorong perkembangan teknologi dan penciptaan inovasi baru. Perkembangan teknologi sangat maju sehingga berdampak dengan lahirnya era yang disebut era disruptif dimana teori inovasi yang ada sekarang, harus terus dikembangkan dan dapat mengancam keberadaan dari teknologi yang ada sekarang. Akibat dari Disruptif ini adalah terjadinya perubahan signifikan secara mendasar serta meluasnya usaha-usaha inovasi teknologi dalam hal hubungan antar manusia dalam segala bidang tidak terkecuali proses belajar mengajar di perguruan tinggi. Bila dipandang dari sisi kuantitatif, tingkat pertumbuhannya sangat pesat; akan tetapi apabila di hubungkan dengan kualitasnya, perkembangannya dapat mencemaskan. Oleh karenanya, perguruan tinggi, harus dapat berkompetisi dalam merubah sistem pembelajaran yang mengikuti pola inovasi yang disruptif dalam rangka meningkatkan mutu proses pembelajaran yang berdampak pada peningkatan mutu Sumber Daya Manusianya.

Untuk meningkatkan proses pendidikan dan pengajaran oleh dosen, pembelajaran dapat dilakukan dengan menggunakan teknologi Blended Learning (Suwarno \& Hendi, 2018) (Noh, Abdullah, Teck, \& MahizerHamzah, 2019) (AlKhaleel, 2019). Teknologi Blended Learning merupakan teknologi untuk mendukung mahasiswa agar lebih memahami materimateri dengan menggunakan alat bantu secara visual baik dengan tutorial, simulasi, atau gambar. Teknologi Blended Learning ini juga memanfaatkan platform online di kampus baik internet maupun intranet yang mempunyai tujuan untuk menyederhanakan topik-topik yang kompleks melalui pembuatan simulasi dan juga modul-modul yang interaktif untuk mendukung pemahaman mahasiswa terhadap topik-topik yang dibahas dalam proses pembelajaran.

Teknologi Blended Learning berpengaruh signifikan terhadap kompetensi mahasiswa (Suwarno \& Hendi, 2018); akan tetapi dalam penelitian ini akan diteliti bahwa bagaimana bagaimana penerimaan teknologi blended learning oleh mahasiswa di kota batam dengan metode unified theory of acceptance and use of technology (Venkatesh, Morris, Davis, \& Davis, 2003).

\section{TINJAUAN PUSTAKA}

\section{A. Blended Learning}

Istilah dari blended learning sudah dipakai dimulai sejak adanya perkembangan dari teknologi Internet dan juga World Wide Web di abad yang ke-20 ini. Konsep secara pedagogikal dari istilah blended learning merupakan suatu strategi yang berhasil melakukan kombinasi e-learning dengan pembelajaran tatap muka dan atau kolaborasi secara online (Seeland, et al., 2016). Blended learning didefinisikan sebagai Blended Learning adalah kombinasi dari dua pengajaran pedagogi tradisional tatap muka dan E-Learning (Ismail, Shahdan, \& Yulia, 2019) dan juga dikatakan merupakan campuran kegiatan kelas yang direncanakan secara online dan tradisional tatap muka (Todaka, 2019). Blended learning yang digunakan pada penelitian ini 
mengacu pada definisi dari Ismail, Shahdan dan Yulia.

\section{B. Unified Theory of Acceptance and Use of Technology (UTAUT)}

Page|231 UTAUT dikemukakan oleh Venkatesh et al. (Venkatesh, Morris, Davis, \& Davis, 2003), yang memberikan penjelasan bahwa dalam hal prilaku dalam penggunaan teknologi informasi, hal ini dipengaruhi dengan kondisi fasilitasi, pengaruh sosial, ekspektasi kinerja, dan ekspektasi upaya. Tiga buah yang berasal dari variabel-variabel independen (EE, PE, SI) akan melalui variabel intervensi niat perilaku, variable lainnya juga memfasilitasi kondisi langsung yang berdampak kepada perilaku penggunaan. Venkatesh et al. juga menambahkan suatu variabel moderasi didalam suatu skema penelitian. UTAUT memakai data nominal ini untuk memperoleh pengertian tentang karakteristik dari kelompok pemakai yang berbeda. UTAUT mengusulkan bahwa harapan kinerja, upaya harapan, dan pengaruh sosial memprediksi niat perilaku terhadap penerimaan teknologi informasi (Taiwo \& Downe, 2013).

\section{METODE PENELITIAN}

\section{A. Pendekatan Penelitian}

Penelitian ini adalah penelitian yang berupa pendekatan kuantitatif yang dilakukan melihat hasil daripada penerapan teknologi Blended Learning. Waktu penelitian diselenggarakan selama empat bulan yakni pada semester genap tahun ajaran 2019/2020. Tempat penelitian dilaksanakan pada perguruan tinggi di Kota Batam.

Penelitian kuantitatif berdasarkan pada populasi dari jumlah mahasiswa di kota Batam sebanyak 20525 orang (Kementerian Riset T. d., Grafik Jumlah Mahasiswa Aktif Berdasarkan Jenis Kelamin, 2019) dan perguruan tingginya mempunyai website elearning. Jumlah kuesioner yang akan dikirimkan akan dihitung berdasarkan pada rumus sampling terhadap populasi sebanyak 100 mahasiswa di provinsi Kepulauan Riau pada semester ganjil tahun 2019, dengan tingkat pengembalian (response rate) yang diharapkan sebesar $100 \%$ atau kembali seluruhnya.

Ukuran sampel menggunakan formula Slovin dengan perhitungan sebagai berikut:

$$
\mathrm{n}=\mathrm{N} /((\mathrm{Nxd} 2)+1)
$$

dimana $\mathrm{n}$ adalah sampel, $\mathrm{N}=$ populasi, $\mathrm{d}=$ margin error, sehingga diperoleh perhitungan sebagai berikut:

$$
\mathrm{n}=20803 /((20803 \times 10 \% 2)+1)=99,5=100
$$

Jumlah sampel yang digunakan dalam penelitian ini adalah minimal 100 orang mahasiswa.

\section{B. Metode Pengumpulan Data}

Metode pengumpulan data dalam penelitian ini menggunakan convenience sampling. Setiap mahasiswa program pembelajaran online dan pembelajaran jarak jauh dapat menjadi sampel, selama perguruan tingginya menyelenggarakan eLearning. Kuisioner dikumpulkan melalui kuisioner manual dan elektronik (e-kuesioner). Manual diberikan langsung kepada siswa, sementara ekuesioner didistribusikan melalui Google docs, tautan ke kuesioner didistribusikan di forum pembelajaran online, aplikasi ponsel, dan email. Kuesioner menggunakan skala Likert dari skala 1 sampai 5. Skala 1 sangat tidak setuju dan skala 5 sangat setuju.

Sebelum survey didistribusikan pada keseluruhan responden, peneliti melaksanakan penelitian pendahuluan melalui cara penyebaran 30 kuesioner untuk melaksanakan uji validitas dan juga uji reliabilitas. Setelah penyebaran dari penelitian pendahuluan dilaksanakan, diambil sample sebanyak $100+10 \%=110$ dimana dari 5 perguruan tinggi yang menjadi responden (sudah punya situs elearning: lihat tabel 1 di bawah), sebanyak 30 responden akan diminta untuk mengisikan survey pendahuluan yang digunakan pada penelitian ini.

\section{Variabel Penelitian}

Berdasarkan kerangka dari konseptual penelitian yang telah dipaparkan, variabel-variabel penelitian ini dapat diklasifikasikan sebagai berikut:

\section{1) Variabel Independen}

Variabel penelitian yang menjadi variabel independen adalah Performance Expectancy (PE), Effort Expectancy (EE), Social Influence (SI), Facilitating Conditions (FC). Peneliti (Venkatesh, Thong, \& Xu, Unified Theory of Acceptance and Use of Technology: A Synthesis and the Road Ahead, 2016) menjelaskan dan mendeskripsikan empat buah konstruksi utama dari UTAUT yaitu:

a. Ekspektasi kinerja = EK (performance expectancy) didefinisikan oleh peneliti sebagai seberapa besar seseorang dapat percaya untuk menggunakan sebuah sistem yang akan membantu dia untuk mendapatkan keuntungan dari kinerja pekerjaannya.

b. Ekspektasi usaha = EU (effort expectancy), didefinisikan oleh peneliti sebagai seberapa mudah keterhubungan dengan pemakaian suatu system yang ada. Jika sistem ternyata mudah digunakan, usaha yang dilakukan kemudian jadi tidak akan sangat tinggi dan begitu juga sebaliknya jika ditemukan suatu sistem ternyata sulit untuk digunakan maka 
dibutuhkan usaha yang tingkat tinggi untuk menggunakan sistem tersebut.

c. Pengaruh sosial $=$ PS ( social influence), oleh peneliti didefinisikan sebagai seberapa jauh mana seorang individu dapat mempersepsikan suatu kepentingan yang dapat dipercaya oleh orang yang lain yang mempengaruhinya dalam menggunakan sistem baru.

d. Kondisi fasilitas $=\mathrm{KF}$ (facilitating condition) didefinisikan sebagai seberapa jauh seseorang dapat percaya mengenai infrastruktur organisasional dan juga teknikal yang tersedia dalam rangka mendukung sistem.

\section{2) Variabel Dependen}

Variabel penelitian yang menjadi variable dependen adalah Use Behavior (UB). Peneliti (Venkatesh, Thong, $\& \mathrm{Xu}$, Unified Theory of Acceptance and Use of Technology: A Synthesis and the Road Ahead, 2016) menjabarkan dan mendeskripsikan use behavior (Penerimaan Teknologi Blended Learning) dari UTAUT yaitu Use Behavior (penerimaan) didefinisikan sebagai tingkat kepuasan dan tingkat kepentingan dari teknologi Blended Learning.

\section{Model Penelitian}

Model penelitian yang digunakan pada penelitian ini adalah sebagai berikut:

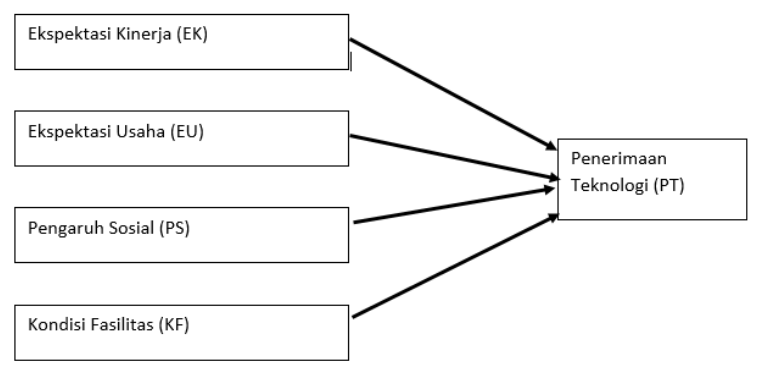

Gbr. 1 Model Penelitian Sumber: Olahan Peneliti, 2020

\section{E. Pengembangan Hipotesis}

Hipotesis dalam penelitian ini disusun sebagai berikut:

H1: Ekspektasi Kinerja berpengaruh signifikan terhadap Penerimaan Teknologi Blended Learning.

$\mathrm{H} 2$ : Ekspektasi Usaha berpengaruh signifikan terhadap Penerimaan Teknologi Blended Learning.

H3: Pengaruh Sosial berpengaruh signifikan terhadap Penerimaan Teknologi Blended Learning.

H4: Kondisi Fasilitas memiliki pengaruh yang signifikan terhadap Penerimaan Teknologi Blended Learning.

\section{HASIL DAN PEMBAHASAN}

Penelitian ini menggunakan cara pengumpulan data dengan menyebarkan kuesioner melalui penyebaran secara langsung kepada mahasiswa PTS di provinsi kepulauan Riau, melalui penyebaran langsung lewat media sosial dari peneliti ke perguruan tinggi di berbagai tempat di provinsi Kepri.

Responden dipilih secara acak dan dengan menggunakan pertimbangan bahwa mereka adalah mahasiswa perguruan tinggi sehingga dapat merasakan bagaimana teknologi Blended Learning dari perguruan tinggi mereka.

\section{A. Data Penelitian}

Kuesioner yang disebarkan kepada sejumlah 186 responden. Kuesioner ini mulai disebarkan pada Universitas Batam, Universitas Internasional Batam, Universitas Riau Kepulauan, Universitas Putera Batam, dan Universitas Universal. Penyebaran survei dilaksanakan tanggal 1 Mei 2020 sampai 10 Mei 2020 dengan batas waktu pengembalian adalah pada tanggal 29 Mei 2020. Keseluruhan kuesioner telah terkumpul sebanyak 184 kuesioner yang layak pakai, dua kuesioner lagi tidak valid dikarenakan bukan berstatus mahasiswa. Sesuai dengan jumlah sampel yang diinginkan, maka dipakai 184 kuesioner. Kuesioner yang digunakan pada penelitian ini adalah 184 kuesioner.

Berdasarkan hasil olah penelitian, data profil responden tersebut menunjukkan bahwa $26,1 \%$ data atau 48 orang berasal dari program studi Akuntansi; $2,2 \%$ atau 4 orang berasal dari program studi Ilmu Hukum; 6,5\% atau 12 orang berasal dari program studi Manajemen; $1,6 \%$ atau 3 orang berasal dari program studi Pendidikan Bahasa Inggris; 61,4\% atau 113 orang berasal dari program studi Sistem Informasi; 1,6\% atau 3 orang berasal dari program studi Teknik Sipil; dan $0,5 \%$ atau 1 orang berasal dari program studi Teknologi Informasi. Data ini menggambarkan bahwa responden berasal dari berbagai program studi dari Universitas yang berada di provinsi Kepri.

Profil responden juga menunjukkan kategori jenis kelamin responden penelitian, bahwa responden perempuan sebanyak 79 orang atau senilai 42,9\% dan responden laki-laki sebanyak 105 orang atau senilai $57,1 \%$. Hal ini wajar mengingat bahwa dikarenakan sebagian besar responden berasal dari jurusan di bidang sains dan teknologi (Sistem Informasi, Teknologi Informasi dan Teknik Sipil) yaitu 63,5\% dan biasanya pada jurusan sains dan teknologi di provinsi Kepri memiliki kecenderungan banyak mahasiswa Laki-Laki. Profil responden juga menunjukkan kategori umur responden penelitian, bahwa umur responden yang lebih kecil dari 26 tahun adalah sebanyak 180 orang atau 
senilai $97,8 \%$ dan umur responden yang berada pada lingkup 26-30 tahun sebanyak 4 orang atau senilai $2,2 \%$. Hal ini wajar mengingat bahwa provinsi Kepulauan Riau adalah provinsi yang memiliki banyak pendatang, dan umumnya adalah lulusan dari Sekolah Menengah Kejuruan maupun Sekolah Menengah Atas dari provinsi Kepulauan Riau, sehingga rata-rata masih berusia muda dan fresh graduate dari sekolahnya.

Profil responden pada kategori status pekerjaan responden penelitian bahwa mahasiswa yang tidak bekerja adalah sebanyak $54,3 \%$ atau 100 orang responden, sedangkan sisanya sebanyak $45,7 \%$ atau 85 orang adalah mahasiswa yang bekerja sambil kuliah. Hal ini dapat dijelaskan bahwa pada umumnya mahasiswa yang berada di provinsi Kepulauan Riau sebagian sudah bekerja pada saat mereka memasuki bangku kuliah dikarenakan banyak tersedia lowongan bagi mereka dari industri di provinsi Kepulauan Riau pada umumnya; dan di kota Batam pada khususnya.

Berdasarkan hasil olah penelitian, dapat dilihat bahwa Ekspektasi Kinerja dipersepsikan moderat oleh responden $(3,39)$, hal ini ditunjukkan dengan nilai-ratarata jawaban yang berada di kisaran kategori moderat. Indikator Ekspektasi Kinerja yang dinilai paling tinggi oleh responden adalah Kegunaan (3,54);sedangkan indikator Ekspektasi Kinerja yang dinilai paling rendah oleh responden adalah Kinerja (3,23). Ekspektasi Usaha dipersepsikan tinggi oleh responden $(3,56)$, hal ini ditunjukkan dengan nilai-rata-rata jawaban yang berada di kisaran kategori tinggi. Indikator Ekspektasi Usaha yang dinilai paling tinggi oleh responden adalah Kemudahan Penggunaan (3,58);sedangkan indikator Ekspektasi Usaha yang dinilai paling rendah oleh responden adalah Kemudahan Pencarian (3,47). Pengaruh Sosial dipersepsikan tinggi oleh responden $(3,52)$, hal ini ditunjukkan dengan nilai-rata-rata jawaban yang berada di kisaran kategori tinggi. Indikator Pengaruh Sosial yang dinilai paling tinggi oleh responden adalah Dukungan Pimpinan Kampus $(3,74)$;sedangkan indikator Pengaruh Sosial yang dinilai paling rendah oleh responden adalah Pengaruh Teman Sejawat $(3,22)$. Kondisi fasilitas dipersepsikan tinggi oleh responden $(3,67)$, hal ini ditunjukkan dengan nilairata-rata jawaban yang berada di kisaran kategori tinggi. Indikator Kondisi fasilitas yang dinilai paling tinggi oleh responden adalah Pengetahuan Yang Dimiliki (3,91);sedangkan indikator Kondisi fasilitas yang dinilai paling rendah oleh responden adalah Dukungan Infrastruktur $(3,22)$. Penerimaan Teknologi Blended Learning dipersepsikan moderat oleh responden $(3,22)$, hal ini ditunjukkan dengan nilai-ratarata jawaban yang berada di kisaran kategori sedang. Indikator Penerimaan Teknologi Blended Learning yang dinilai paling tinggi oleh responden adalah Merencanakan $(3,26)$;sedangkan indikator Penerimaan
Teknologi Blended Learning yang dinilai paling rendah oleh responden adalah Mempunyai Niat $(3,17)$.

Setelah data dinyatakan valid dan reliabel berdasarkan uji validitas dan reliabilitas, dimana corrected item-total correlation lebih besar dari 0,3 dan nilai Cronbach's alpha sebesar 0,904 maka ada empat item pertanyaan yang tidak valid dan tidak diikutsertakan pada analisis regresi yang dilakukan.

Berdasarkan hasil pengolahan data, nilai signifikansi dari uji $\mathrm{F}$ adalah sebesar 0,000 dan lebih kecil daripada 0,05 , oleh karenanya dapat disimpulkan bahwa variable dependen Kondisi Fasilitas, Ekspektasi Usaha, Ekspektasi Kinerja, dan Pengaruh Sosial, secara bersama-sama berpengaruh terhadap variabel independen Penerimaan Teknologi Blended Learning. Besarnya pengaruh dari variabel independen terhadap variabel dependen adalah $49,9 \%$ sedangkan $50,1 \%$ sisanya dipengaruhi oleh faktor lainnya yang berada di luar dari persamaan model regresi ini atau variabel yang belum diteliti pada model ini. Dapat disimpulkan bahwa nilai 49,9\% sudah dikatakan baik, dikarenakan data yang dikumpulkan bersifat data primer langsung dari responden penelitian.

\section{KESIMPULAN}

1. Responden didalam penelitian yang telah dilakukan ini, berjumlah 184 responden yang secara keseluruhan adalah mahasiswa perguruan tinggi di provinsi Kepulauan Riau yang berstatus aktif dan teregistrasi dalam perkuliahan di tahun akademik 2019/2020 dan kampusnya mempunyai website elearning (Universitas Internasional Batam dengan website https://elearning.uib.ac.id/, Universitas Putera Batam dengan website http://elearning.upbatam.ac.id/, Universitas Batam dengan website http://elearning.univbatam.ac.id/, Universitas Riau Kepulauan dengan website https://www.unrika.ac.id/e-learning, dan Universitas Universal dengan website http://elearning.uvers.ac.id/ ). Profil elearning menunjukkan paling tidak mahasiswa sudah memiliki pengalaman dalam menggunakan, mengimplementasikan kuliah dan melakukan berbagai aktifitas berbagi dengan dosen secara online, sehingga mahasiswa dapat menjawab secara keseluruhan pertanyaan yang diajukan pada kuesioner ini. Data profil responden tersebut menunjukkan bahwa $26,1 \%$ data atau 48 orang berasal dari program studi Akuntansi; 2,2\% atau 4 orang berasal dari program studi Ilmu Hukum; 6,5\% atau 12 orang berasal dari program studi Manajemen; 1,6\% atau 3 orang berasal dari program studi Pendidikan Bahasa Inggris; 61,4\% atau 113 orang berasal dari program studi Sistem Informasi; 
$1,6 \%$ atau 3 orang berasal dari program studi Teknik Sipil; dan $0,5 \%$ atau 1 orang berasal dari program studi Teknologi Informasi. Data ini menggambarkan bahwa responden berasal dari berbagai program studi dari Universitas yang berada di provinsi Kepri. Profil responden kemudian juga menunjukkan kategori jenis kelamin responden penelitian, bahwa responden perempuan sebanyak 79 orang atau senilai $42,9 \%$ dan responden laki-laki sebanyak 105 orang atau senilai $57,1 \%$. Hal ini wajar mengingat bahwa dikarenakan sebagian besar responden berasal dari jurusan di bidang sains dan teknologi (Sistem Informasi, Teknologi Informasi dan Teknik Sipil) yaitu 63,5\% dan biasanya pada jurusan sains dan teknologi di provinsi Kepri memiliki kecenderungan banyak mahasiswa Laki-Laki. Profil responden juga menunjukkan kategori umur responden penelitian, bahwa umur responden yang lebih kecil dari 26 tahun adalah sebanyak 180 orang atau senilai $97,8 \%$ dan umur responden yang berada pada lingkup 26-30 tahun sebanyak 4 orang atau senilai $2,2 \%$. Hal ini wajar mengingat bahwa provinsi Kepulauan Riau adalah provinsi yang memiliki banyak pendatang, dan umumnya adalah lulusan dari Sekolah Menengah Kejuruan maupun Sekolah Menengah Atas dari provinsi Kepulauan Riau, sehingga rata-rata masih berusia muda dan fresh graduate dari sekolahnya. Profil responden selanjutnya menunjukkan kategori status pekerjaan responden penelitian bahwa mahasiswa yang tidak bekerja adalah sebanyak $54,3 \%$ atau 100 orang responden, sedangkan sisanya sebanyak $45,7 \%$ atau 85 orang adalah mahasiswa yang bekerja sambil kuliah. Hal ini dapat dijelaskan bahwa pada umumnya mahasiswa yang berada di provinsi Kepulauan Riau sebagian sudah bekerja pada saat mereka memasuki bangku kuliah dikarenakan banyak tersedia lowongan bagi mereka dari industri di provinsi Kepulauan Riau pada umumnya; dan di kota Batam pada khususnya.

2. Hasil dari estimasi nilai variabel Ekspektasi Usaha terhadap Penerimaan Teknologi Blended Learning berlandaskan dari indikator-indikatornya memperlihatkan suatu taraf signifikansi 0.000 yang ini berarti berada pada nilai yang lebih kecil dari nilai cut off yaitu 0.05 . Hal ini menunjukkan bahwa hasil pengujian kausalitas penelitian menunjukkan bahwa pengaruh variabel Ekspektasi Usaha terhadap Penerimaan Teknologi Blended Learning adalah signifikan. Keberhasilan sivitas akademika perguruan tinggi dalam mensosialisasikan elearning pada mahasiswa agar memiliki usaha untuk mempelajari elearning dalam proses pembelajaran mendorong usaha yang kuat dari mahasiswa dalam menerima teknologi Blended Learning.
3. Hasil dari estimasi nilai variabel Ekspektasi Usaha terhadap Penerimaan Teknologi Blended Learning berlandaskan dari indikator-indikatornya memperlihatkan suatu taraf signifikansi 0.157 yang ini berarti berada pada nilai yang lebih besar dari nilai cut off yaitu 0.05 . Hal ini didapat dari hasil pengujian kausalitas penelitian yang menunjukkan bahwa pengaruh variabel Ekspektasi Kinerja terhadap Penerimaan Teknologi Blended Learning adalah tidak signifikan. Mahasiswa masih belum menerima bahwa Teknologi Blended Learning dapat meningkatkan kinerja mereka. Hal ini dapat dilihat dari kenyataan bahwa teknologi Blended Learning bukanlah sesuatu hal yang baru bagi mahasiswa pada masa sekarang. Mahasiswa sudah merasa bahwa yang dilakukan oleh eLearning belum meningkatkan kinerja mereka dan cenderung masih mempelajari bagaimana eLearning bekerja, dan juga dikarenakan oleh kebiasaan mahasiswa sekarang yang sudah beradaptasi dengan teknologi yang sudah berbasis digital duluan. Hal ini menjadi masukan bagi perguruan tinggi untuk mendorong mahasiswanya untuk merasakan peningkatan kinerja dalam proses belajar mengajar di perguruan tinggi.

4. Hasil dari estimasi nilai variabel Pengaruh Sosial terhadap Penerimaan Teknologi Blended Learning berlandaskan dari indikator-indikatornya memperlihatkan suatu taraf signifikansi 0.011 yang ini berarti berada pada nilai yang lebih kecil dari nilai cut off yaitu 0.05 . Hal ini menunjukkan bahwa pengaruh variabel Pengaruh Sosial terhadap Penerimaan Teknologi Blended Learning adalah signifikan. Keberhasilan dari perguruan tinggi dalam melakukan sosialisasi lewat berbagai cara termasuk dorongan dari segenap sivitas akademika, teman sejawat, pimpinan program studi, dan pimpinan kampus sejalan dengan peningkatan penerimaan mahasiswa terhadap teknologi Blended Learning yang didorong oleh lingkungan sosialnya.

5. Hasil dari estimasi nilai variabel Kondisi Fasilitas terhadap Penerimaan Teknologi Blended Learning berlandaskan dari indikator-indikatornya memperlihatkan suatu taraf signifikansi 0.005 yang ini berarti berada pada nilai yang lebih kecil dari nilai cut off yaitu 0.05 . Hal ini menunjukkan bahwa pengaruh variabel Kondisi Fasilitas terhadap Penerimaan Teknologi Blended Learning adalah signifikan. Penyediaan sarana dan prasarana di perguruan tinggi terbukti mempengaruhi secara signifikan terhadap Penerimaan mahasiswa terhadap teknologi Blended Learning. Perguruan tinggi di kota Batam telah siap dalam menyelenggarakan perkuliahan dengan menggunakan basis digital dan mahasiswa di kota Batam telah memiliki sarana dan prasarana yang memungkinkan teknologi Blended 
Learning dapat diakses dan digunakan dalam proses pembelajaran.

6. Hasil dari nilai signifikansi dari uji $\mathrm{F}$ adalah sebesar 0,000 dan lebih kecil daripada 0,05, oleh karenanya dapat disimpulkan bahwa variable dependen Kondisi Fasilitas, Ekspektasi Usaha, Ekspektasi Kinerja, dan Pengaruh Sosial, secara bersama-sama berpengaruh terhadap variabel independen Penerimaan Teknologi Blended Learning. Hal ini memperlihatkan bahwa keseluruhan Penerimaan Teknologi Blended Learning di kalangan mahasiswa sudah dapat diterima dengan baik.

\section{REFERENSI}

[1] H. Budiman, "Peran Teknologi Informasi dan Komunikasi Dalam Pendidikan," Al-Tadzkiyyah: Jurnal Pendidikan Islam, pp. 75-83, 2017.

[2] T. d. P. T. Kementerian Riset, "Grafik Jumlah Mahasiswa Aktif Berdasarkan Jenis Kelamin,” 11 Des 2019. [Online]. Available: forlap.ristekdikti.go.id/mahasiswa/homegraphjk.

[3] T. d. P. T. Kementerian Riset, "Grafik Jumlah Dosen Aktif Berdasarkan Jenis Kelamin,” 11 Desember 2019. [Online]. Available: forlap.ristekdikti.go.id/dosen/homegraphjk.

[4] C. I. WIPO, "2019 Report," 11 December 2019. [Online]. Available: www.globalinnovationindex.org/gii-2019-report.

[5] W. Yuwono, "Perancangan Model Framework Manajemen Strategik Planning Sektor Pariwisata Di Provinsi Kepulauan Riau," Journal of Accounting \& Management Innovation, pp. 14-25, 2018.

[6] Akhirman, "Analisa Pengelolaan Sektor Pariwisata Terhadap Pertumbuhan Ekonomi Di Kepri Tahun 2015-2016," Jurnal Bahtera Inovasi,, pp. 104-110, 2019.

[7] A. Hendrayady, "Strategi Pembangunan Wilayah Perbatasan Provinsi Kepulauan Riau," Jurnal Ilmu Administrasi Negara, pp. 1-10, 2018.

[8] Sinarti, D. Karikasari, B. Hendrawan dan A. Wibowo, "Pengukuran Tingkat Daya Saing Kabupaten/Kota Di Provinsi Kepri," Jurnal Akuntansi, Ekonomi dan Manajemen Bisnis, pp. 179-190, 2018.

[9] Suwarno dan Hendi, "Analisis Pengaruh Blended Learning dan Sertifikasi Terhadap Kompetensi Mahasiswa," Computer Based Information System Journal, pp. 1-8, 2018.

[10] N. M. Noh, N. Abdullah, W. K. Teck dan MahizerHamzah, "Cultivating Blended Learning in Teaching and Learning: Teachers' Intrinsic and Extrinsic Readiness in Malaysia," International Journal of Academic Research in Progressive Education \& Development, pp. 257-265, 2019.

[11] A. AlKhaleel, "The Advantages of Using Blended Learning in Studying English as a Foreign Language at the University of Tabuk," Modern Journal of Language Teaching Methods, pp. 17, 2019.

[12] V. Venkatesh, M. G. Morris, G. B. Davis dan F. D. Davis, "User Acceptance of Information Technology: Toward a Unified View," MIS Quarterly, pp. 425-478, 2003.

[13] U. Seeland, A. T. Nauman, A. Cornelis, S. Ludwig, M. Dunkel dan G. Kararigas, "eGender-from e-Learning to e-Research:a Web-Based Interactive Knowledge-Sharing Platform for Sexand Gender-Specific medical Education," Biology of Sex Differences, pp. 83-91, 2016.

[14] A. R. Ismail, T. S. T. Shahdan dan A. Yulia, "A Review of Blended Learning for Education," International Journal of Scientific and Research Publications, pp. 145-148, 2019.
[15] Y. Todaka, "Modified Blended Learning: De-motivated Japanese College EFL Learners Sustain Motivation to Improve English Listening Skills," International Journal of Innovation and Research in Educational Sciences, pp. 263-284, 2019.

[16] A. A. Taiwo dan A. G. Downe, "The Theory of User Acceptance and Use of Technology (UTAUT): A MetaAnalytic Review of Empirical Finding," Journal of Theoretical and Applied Information Technology, pp. 48-58, 2013.

[17] V. Venkatesh, J. Y. L. Thong dan X. Xu, "Unified Theory of Acceptance and Use of Technology: A Synthesis and the Road Ahead," Journal of the Association for Information System, pp. 328-376, 2016.

[18] Sugiyono, Metode Penelitian Manajemen, Bandung: Alfabeta, 2014.

[19] T. d. P. T. R. I. Kementerian Riset, Buku Lanskap Ilmu Pengetahuan dan Teknologi Indonesia 2017, Jakarta: Kementerian Ristekdikti RI, 2017.

[20] P. Apriliani, I. R. Husen dan D. Hilmanto, "The Influence Of Asynchronous Blended Problem-Based Learning On Retention And Learning Motivation Of Midwifery Students," Jurnal Pendidikan Kedokteran Indonesia, pp. 91-96, 2019.

[21] V. S. Chouhan dan S. Srivastava, "Understanding Competencies and Competency Modeling - A Literature Survey," IOSR Journal of Business and Management, pp. 1422, 2014.

[22] R. Nagarajan dan R. Prabhu, "Competence and Capability - A New Look," International Journal Of Management, pp. 7-11, 2015.

[23] A. Kiyani, S. Liaqut dan M. A. Chuadhry, "Impact of Professional Competency Of Academia On Academic Achievement Of Student At Higher Level," International Journal of Technical Research and Applications, pp. 21-27, 2014.

[24] I. L, "Evaluasi Dalam Proses Pembelajaran," Jurnal Manajemen Pendidikan Islam, pp. 920-935, 2019.

[25] S. Crowe, K. Cresswell, A. Robertson, G. Huby, A. Avery dan A. Sheikh, "The Case Study Approach," BMC Medical Research Methodology, pp. 2-9, 2011.

[26] T. D. P. T. KEMENTERIAN RISET, "Grafik Jumlah Mahasiswa Aktif Berdasarkan Kelompok Bidang,” 17 Desember 2019. [Online]. Available: https://forlap.ristekdikti.go.id/mahasiswa/homegraphbidang.

[27] T. Jihad, E. Klementowicz, P. Gryczka, C. Sharrock, M. Maxfield, Y. Lee dan J. K. Montclare, "Perspectives On Blended Learning Through The On-Line Platform, Lablessons, For Chemistry," Journal Of Technology And Science Education, p. 1, 2018. 